\title{
Euphorbia hirta as a gold mine of high-value phytochemicals: A comprehensive review of its pharmacological activities and possible role against SARS-CoV-2
}

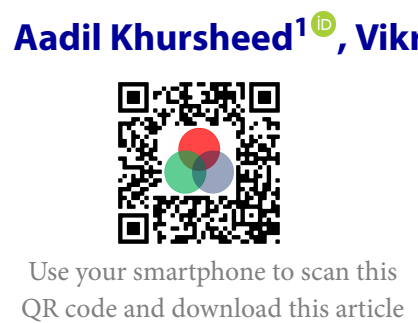

${ }^{1}$ Department of Chemistry,

Madhyanchal Professional University,

Ratibad, Bhopal-462044, M. P, India

${ }^{2}$ Department of Applied Science, Madhyanchal Professional University, Ratibad, Bhopal-462044, M. P, India

${ }^{3}$ Department of Botany, Madhyanchal Professional University, Ratibad,

Bhopal-462044, M. P, India

History

- Received: Nov 26, 2021

- Accepted: Jan 30, 2022

- Published: Feb 28, 2022

DOI : 10.15419/bmrat.v9i2.728

\section{Check for updates}

\section{Copyright}

(c) Biomedpress. This is an openaccess article distributed under the terms of the Creative Commons Attribution 4.0 International license.

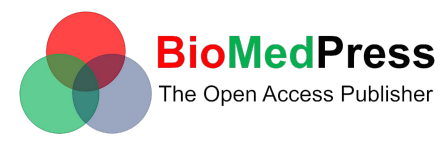

\begin{abstract}
Euphorbia hirta is a common medicinal plant in folk and traditional medicine systems. This plant has shown promising effects against several human ailments and infectious diseases. Therefore, it is important to summarize the medicinal activities and value of Euphorbia hirta. The main intent of this literature review was to summarize the phytochemical content and pharmacological applications of Euphorbia hirta. The literature review about the pharmacology and phytochemistry of Euphorbia hirta was collected from different global platforms, such as Scopus, ERIC, PubMed, and Web of Science. E. hirta has a rich phytochemistry and exhibits remarkable activity against respiratory diseases, gastrointestinal disorders and venereal diseases. Different extracts of this plant have shown significant preclinical anticancer propensity against an array of different cancer cell lines. It acts as a highly active antiviral agent and has shown pronounced activity against coxsackievirus, human immunodeficiency virus, dengue virus, poliovirus and simian immunodeficiency virus. A clinical study showed its inhibitory responses against flu and fever in dengue patients. Most importantly, the plant possesses remarkable inhibitory action on ACE, which aids SARS-CoV-2 entry into host cells. The multidimensional role of Euphorbia hirta as a potential antiviral agent suggests its possible application to control COVID-19 along with modern and Western medicinal strategies. In conclusion, the literature review regarding Euphorbia hirta showed its strong pharmacological applications, such as antimicrobial, antimalarial, anti-asthmatic, antioxidant, antiviral and anticancer activities. Further in-depth research is necessary to monitor its role in the management of viral diseases, especially COVID-19.

Key words: ACE-2, Ethnopharmacology, Euphorbia hirta, Phytochemistry, SARS-CoV-2
\end{abstract}

\section{INTRODUCTION}

Euphorbia hirta is frequently known as "Asthma plant" in English and "Dudhi" in Hindi. The plant is widely distributed throughout the globe, and in Asia, it is mainly found in Yemen, Oman, Palestine, Taiwan, Syria, Lebanon, India, Bhutan, Pakistan, Nepal, Myanmar, Thailand, Sri Lanka, Indonesia, Malaysia, Papua New Guinea and the Philippines ${ }^{1}$. The plant belongs to the genus Euphorbia family of Euphorbiaceae. The morphological features of E. hirta include a slender stem with hair development and many branches arising from it from base to top. The plant is annual purple or reddish in color and attains a height of approximately $40 \mathrm{~cm}$. The leaves of the plant grow oppositely and are elliptical-oblong to oblonglanceolate in shape. The leaves measure up to $1-2.5$ $\mathrm{cm}$ in length with green color on the top side and pale color on the bottom side. The fruits are threecelled, yellow, keeled capsules, hairy, $1-2 \mathrm{~mm}$ in diameter, containing four-sided, three brown, wrinkled, angular, seeds ${ }^{2-5}$. The plant Euphorbia hirta has long served humanity in the form of traditional and folk medicine. In addition to Euphorbia hirta, other species of the genus Euphorbia also show medicinal importance and are being used in traditional medicine. A milky juice comes out of all the species of Euphorbia upon breaking, and this juice is considered to be more/less toxic and hence was used on arrows for hunting purposes in old times ${ }^{6}$. Euphorbia hirta is a high-value medicinal plant possessing significant antimalarial, antifungal, antifertility, antispasmodic, sedative, antiasthmatic, anthelmintic and antibacterial properties ${ }^{2}$. Additionally, the plant has been found to have significant anticancer effects against a variety of aggressive cancer cells.

This review aims to summarize the phytochemical compositions and pharmacological activities of $E u$ phorbia hirta and tries to bridge the possible role of Euphorbia hirta in the management of COVID19, a going on global pandemic. Respiratory tract exposure to the external environment leads to high communicability of the disease. SARS-CoV-2 pa- 
tients differ in clinical symptoms some show evident symptoms, and some remain asymptotic ${ }^{7}$. Asymptomatic patients with SARS-CoV-2 viral loads are the most active transporters leading to the fast spread of the disease because these patients are not aware of the disease until advanced stages. The initial clinical symptoms involve chills, fever, fatigue, cough, diarrhea, shortness of breath and respiratory symptoms. The generation of potential vaccines or capable drugs against SARS-CoV-2 infection is the global emergency right now. Unfortunately, the development of vaccines or potential drugs may take a longer time. Therefore, intermediate treatment methodologies are needed to address this global health issue. The government of the Republic of China is currently emphasizing Traditional Chinese Medicine (TCM) in controlling SARS-CoV-2 infection ${ }^{8,9}$. Several clinical trials have already been initiated to study the efficiency of TCM against SARS-CoV-2 infection. In certain cases, patients along with Western medicine were sidewise supplied with TCM. The results showed that TCM induced synergistic effects with Western medicine against SARS-CoV-2 ${ }^{\mathbf{1 0}}$. Treatments with medicinal plants and herbs are mostly symptoms and sign based. Herbal medicines with potential efficacy against specified targets against viruses could be evaluated for their activity against SARS-CoV-2, reliant on signs and symptoms ${ }^{11,12}$. The prime focus of this review was to summarize the phytochemical constituents and pharmacological and medicinal importance of Euphorbia hirta along with assessing its possibility to be used against COVID-19.

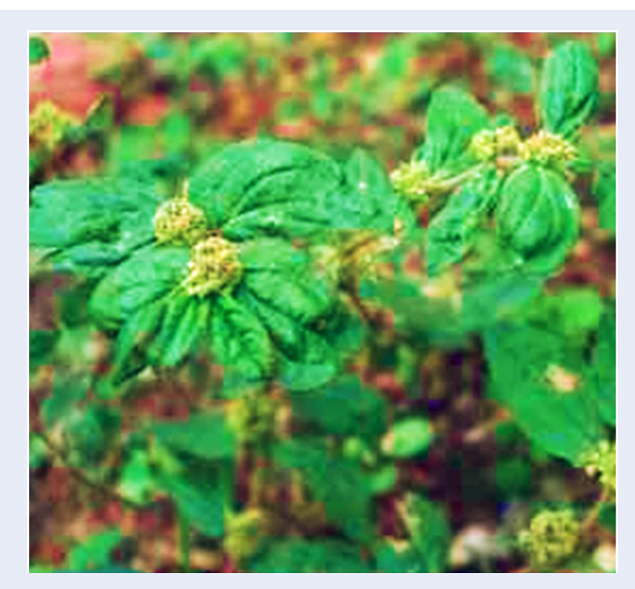

Figure 1: Euphorbia hirta .

\section{EUPHORBIA HIRTA}

E. hirta Linn. (Figure 1) is a small annual, branched herb that can grow to $70 \mathrm{~cm}$ in height, purple or red- dish in color with copious amounts of latex, and covered with sprout hairs.

Leaves: The leaves are opposite, biculate and simple, the stipules are linear, the leaf blade is lanceolate, oblong serrate, long elliptic, tapering, $3-4 \mathrm{~cm}$ long and $1-1.4 \mathrm{~cm}$ wide, and its margin is smoothly serrated.

Flowers: The monoecious inflorescence, an axillary or terminal cluster of flowers, is known as a cyathium, in which several cyathia are arranged in a cyme. The male and female flowers are in a pod and both appellation. The flowers are unisexual, male flowers are sessile, prophylls are linear, fringed, perianth absent and have a stamen, female flowers have a small peduncle, the perianth is fringed, the ovary is covered with tiny hairs above, 3-celled, has 3 - Styles, small and the tip is double. The flowering period is usually year round. Fruit: The fruit is allomorphic, pistillate, elongated, 3-lobed, obtuse base covered with shoot hairs.

Seeds: Seeds are oblong, 4-sided prismatic, wrinkled and brownish pink in color, capsule 3-seeded, green and covered with fleshy spines, seeds smooth, hard mottled crustal skin with a white caruncle at the top enclosing oily endosperm ${ }^{13-19}$.

Roots: The root is a distinct and developed primary root (taproot system).

Classification: E. hirta Linn. belongs to the Euphorbiaceae family, known as the Spurge family. It is the largest family, consisting of almost 300 genera and 5000 species. Euphorbia is the largest genus of the Euphorbiaceae family and includes approximately 1600 species.

\section{BIOACTIVE SECONDARY METABOLITES FROM EUPHORBIA HIRTA}

Plants are a source of highly active biological principles, making them helpful to humanity in regard to tackling key issues, including health ${ }^{\mathbf{2 0 , 2 1}}$. The plant bears a wide variety of phytochemicals, including reducing sugars, alkaloids, terpenoids, flavonoids, tannins, steroids, fats, proteins, gums, oils, mucilage, saponins, glycosides, cardiac glycosides, coumarins, anthraquinones and phenolic compounds ${ }^{22}$. Some of the important phytochemical constituents are summarized in Figure 2. The methanolic extract of Euphorbia hirta has been identified with ten compounds, including palmitic acid, chloromorpholin4-ium, S-methyl-L-cysteine, nicotinic acid, methyl 14-methylpentadecanoate, 2,3,5-trimethyl-1 Hpyrrole, 5-methyl-1,3-oxazolidin-2-one, 2-amino3-sulfanylpropanoic acid, 17-carboxyheptadec-9en-1-ylium and 4-amino-4-oxobut-2-enoic acid ${ }^{23}$. 


\begin{tabular}{ll}
\hline Kingdom & Plantae \\
Division & Spermatomatophyta \\
Class & Dicotyledonae \\
Order & Euphorbiales \\
Family & Euphorbiaceae \\
Genus & Euphorbia \\
Species & Hirta \\
\hline
\end{tabular}
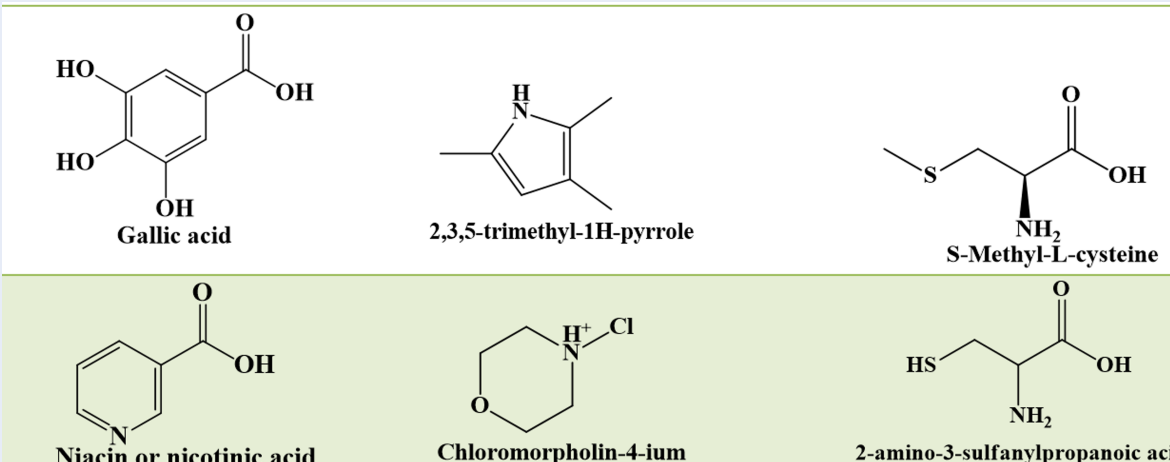

S-Methyl-L-cysteine

Niacin or nicotinic acid

Chloromorpholin-4-ium
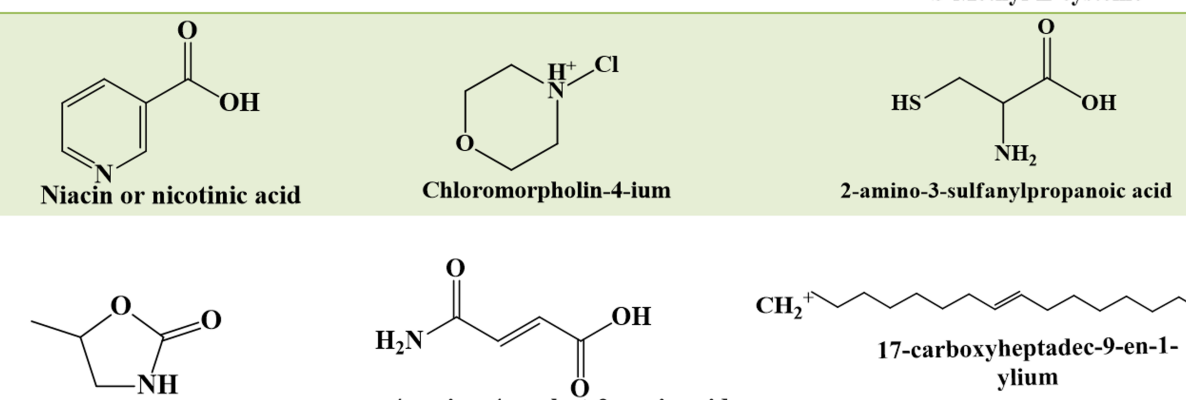

5-methyl-1,3-oxazolidin-2-one
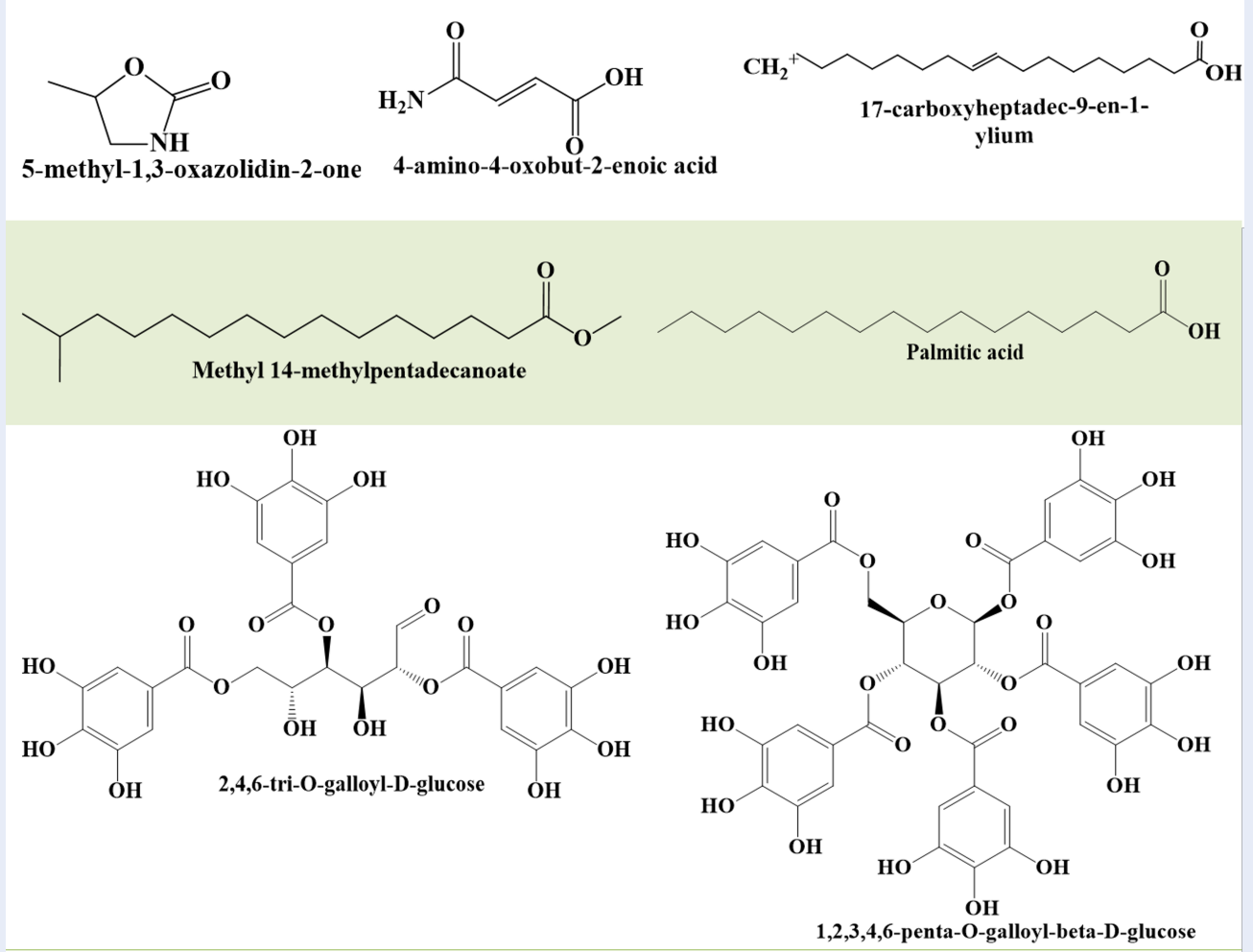

Figure 2: Structure of some of the phytochemical constituents from E. hirta. 


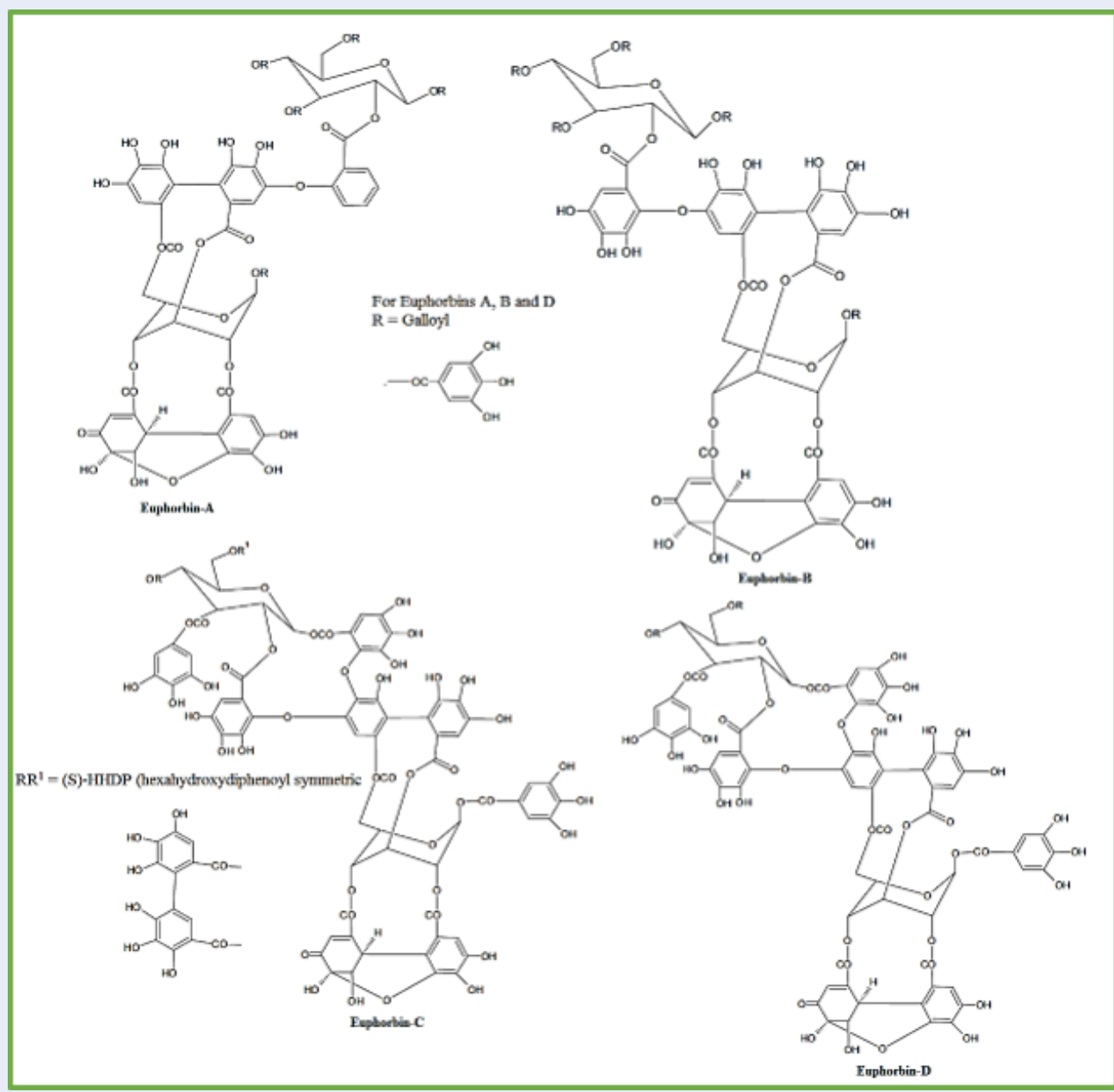

Figure 3: Euphorbins (A-D) from E. hirta.

Six compounds were identified and isolated from $E$. hirta leaves: 3,4-di-O-galloylquinic acid, gallic acid, myricitriu, quercitrin, 1,2,3,4,6-penta-O-galloylbeta- $D$-glucose and 2,4,6-tri-O-galloyl-D-glucose ${ }^{24}$. Aerial parts of the plant were identified with quercitrin, afzelin, 1,3,4,6-tetra-O-galloyl- $\beta$-dglucose, 2,4,6-tri-O-galloyl- $\beta$-d-glucose, euphorbins A-D (Figure 3), myricitrin, kaempferol, rutin, quercetin, gallic acid, and protocatechuic acid ${ }^{25}$. Furthermore, $11 \alpha, 12 \alpha$-oxidotaraxerol, $\alpha$-amyrin, $\beta$-amyrin, taraxerone, $\beta$-amyrin acetate, taxerol, tannins and taraxerone have been reported from plants. Moreover, $\beta$-sitosterol, $\alpha$-amyrin, 24-methylencycloartenol, camphol, leucocyanidol, euphorbianin and euphorbins A-E have also been isolated from the plant.

\section{MEDICINAL PROPERTY OF EUPHORBIA HIRTA}

Different parts of $E$. hirta have shown numerous pharmacological and biological properties. The high biological value of the plant is primarily attributed to its high diversity in phytochemical content. Some of the biological activities are represented in Figure 4.

\section{Ethnopharmacology}

E. hirta has a very high medicinal value. Ethnopharmacologically, E. hirta is used to cure respiratory and bronchial disorders (hay fever, bronchitis and asthma), conjunctivitis and gastrointestinal diseases such as intestinal parasitosis, dysentery and diarrhea. Furthermore, E. hirta shows significant tonic and hypotensive properties ${ }^{26}$. Stem sap of E. hirta is used to cure eyelid styes caused by bacterial infection, and leaves are used against boils and swellings by mak- 


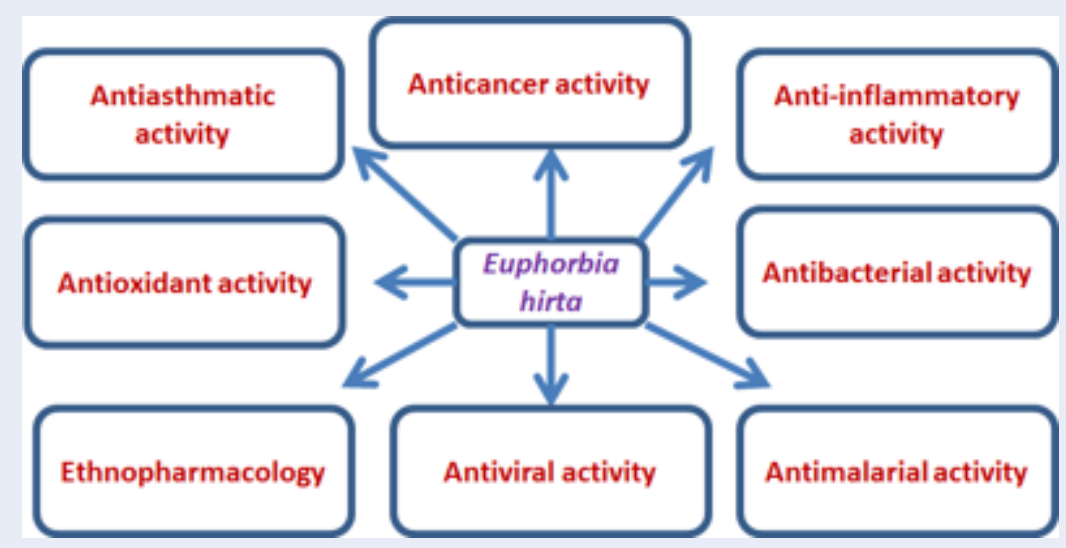

Figure 4: Biological activity profile of Euphorbia hirta.

ing their poultice. The plant as a whole is used by humans against different diseases, such as fresh herb decoction in the treatment of thrush by gargling, dry decoction to cure skin disorders and decoction of roots, which is implemented in snake bites and for milk production in nursing mothers ${ }^{27}$. Antispasmodic and antiamoebic activities have been shown for polyphenolic extracts of the plant ${ }^{28,29}$. Furthermore, the E. hirta-isolated compound quercitrin has been reported to have remarkable antidiarrheal potential $^{30,31}$. It shows reflexive effects on cardiovascular systems in humans, such as the respiratory system $^{32}$. The E. hirta plant alcoholic extracts show tranquilizing effects on the genitor-urinary tract and report hypoglycemic effects in rats ${ }^{33,34}$. The isolated compounds and solvent extracts of E. hirta demonstrated substantial anticancer activities. E. hirta extracts exhibit inhibitory effects on prostaglandin release, including D2, E2 and I2. It has also been reported to produce protective effects against contamination caused by aflatoxin in mustard, rice, maize and wheat crops ${ }^{35}$. Methanolic extracts of E. hirta leaves have been shown to have strong antibacterial and antifungal properties. Itchy soles are treated by pounding, warming and rubbing the leaves of E. hirta with coconut oil and turmeric. Plant latex is used to cure eye sores by applying it to the surma on the lower eyelids. A number of the ethnopharmacological uses of E. hirta are listed in Table $\mathbf{1 .}$

\section{Antibacterial activity}

Ethanolic extraction from E. hirta leaves has been tested for its antibacterial activities against Salmonella typhi, Bacillus subtilis, Pseudomonas aeruginosa, Staphylococcus aureus and Escherichia coli. The extract showed strong inhibition of all these bacteria ex- cept Salmonella typhi. The minimum inhibitory values were calculated to be 74.61, 57.64, 22.55 and 54.09 $\mathrm{mg} / \mathrm{ml}$ for Bacillus subtilis, Pseudomonas aeruginosa, Staphylococcus aureus and Escherichia coli, respectively ${ }^{36}$. Unlike solvent extractions from the stem, bud and leaves of E. hirta, their antimicrobial effects against Staphylococcus aureus were evaluated using the disc-diffusion method. The methanolic extract from leaves and bud exhibited very strong activity against $S$. aureus, with a zone of inhibition score of $20 \mathrm{~mm}$ and a zone of inhibition area score of 471.00 $\mathrm{mm}^{237}$. Chloroform and aqueous fractions of $E$. hirta L. leaves have been reported to possess noncytotoxic but antibacterial effects against Klebsiella pneumonia $^{38}$.

\section{Anti-inflammatory activity}

The medicinal herb E. hirta has been reported to have remarkable anti-inflammatory effects. In a study, the aqueous and ethanolic extracts of E. hirta were evaluated for their anti-inflammatory activity against carrageenan-induced inflammation in rats. It has been shown that both extracts produced substantial anti-inflammatory effects against the reference drug diclofenac sodium $(50 \mathrm{mg} / \mathrm{kg})^{39}$. In a similar study, the lyophilized aqueous extract from $E$. hirta has been reported to suppress inflammation in carrageenaninduced rats starting from the concentrations of 100 $\mathrm{mg} / \mathrm{kg}$ of body weight ${ }^{40}$. Furthermore, $n$-hexane extracts from $E$. hirta have been shown to inhibit inflammation in mouse models of phorbol acetate-induced ear inflammation ${ }^{\mathbf{4 1}}$. The anti-inflammatory effects were found to be concentration-dependent. In another study, fractionated Euphorbia hirta aqueous extract showed in vitro anti-inflammatory activity on rabbit synovial fibroblasts ${ }^{42}$. 
Table 1: Pharmacological activities of $E$. hirta

\begin{tabular}{|c|c|c|}
\hline No & Activity & Action \\
\hline 1 & Anti-allergic activity & $\begin{array}{l}\text { The ethanolic fraction of } E \text {. hirt } a \text { induces inhibitive effects on the discharge of IL- } 6 \\
\text { and TNF- } \alpha \text { in anti-DNP-HAS activated rat peritoneal mast cells. }\end{array}$ \\
\hline 2 & Antibacterial activity & $\begin{array}{l}\text { Different solvent extracts from E. hirta were evaluated for antibacterial ef- } \\
\text { fects Bacillus subtilis, Pseudomonas. aeruginosa, Staphylococcus aureus, and Es- } \\
\text { cherichia coli. The results demonstrated outstanding antibacterial property of } E \text {. } \\
\text { hirta against these pathogen bacteria. }\end{array}$ \\
\hline 3 & Anti-diabetic activity & $\begin{array}{l}\text { The solvent extracts of stem, flower and leaf of } E \text {. hirta showed lowering effects on } \\
\text { overall blood glucose levels on administration to streptozotocin induced diabetic } \\
\text { mice. }\end{array}$ \\
\hline 4 & Anti-diarrheal activity & $\begin{array}{l}\text { The leaves of } E \text {. hirta are rich in flavonoids content especially the quercitin } \\
\text { molecule has been shown to exhibit anti-diarrheal effects through enhancement } \\
\text { in the absorption of colonic fluid in presence of secretagogue compounds. }\end{array}$ \\
\hline 5 & Antioxidant activity & $\begin{array}{l}\text { Antioxidant activity of } E \text {. hirta was shown by performing FRAP and DPPH as- } \\
\text { say and outcomes demonstrated remarkable antioxidant potential of methanolic } \\
\text { extract of } E \text {. hirta by acting against oxidative damage to protein. }\end{array}$ \\
\hline 6 & Antitumor activity & $\begin{array}{l}\text { Research has shown that the methanolic extract of } E \text {. hirta induce antiprolifer- } \\
\text { ative effects in Hep- } 2 \text { cells isolated from human epithelioma of larynx. Hence, } \\
\text { predicting antitumor potency of } E \text {. hirta. }\end{array}$ \\
\hline 7 & $\begin{array}{l}\text { Anxiolytic and seda- } \\
\text { tive activity }\end{array}$ & $\begin{array}{l}\text { The antagonists of the GABAA receptor-benzodiazepine receptor-Cl channel } \\
\text { complex with } E \text {. hirta were used together, and anxiety in the EPM showed marked } \\
\text { anti-anxiety activity in chronic immobilization stress }\end{array}$ \\
\hline 8 & Diuretic activity & $\begin{array}{l}\text { The } E \text {. hirta ethanolic extract on administration to rats augmented the total urine } \\
\text { excretion thus improving diuresis. }\end{array}$ \\
\hline
\end{tabular}

\section{Antioxidant activity}

E. hirta possesses strong antioxidant activities in both animal models and in vitro. It has been shown to have strong free radical scavenging potency in various experimental models using hydroxyl radical scavenging, ABTS, and DPPH assays. The free-radical scavenging ability of the methanolic extract of E. hirta was investigated. The results reported that the methanolic fraction of $E$. hirta leaf extract produced a tremendous DPPH inhibition of $71.96 \pm 0.78 \%$. The increasing order of DPPH scavenging activity of E. hirta was stems $(44.42 \pm 0.94 \%)<$ roots $(48.59 \pm 0.97 \%)<$ flowers $(52.45 \pm 0.66 \%)<$ leaves. The $\mathrm{IC}_{50}$ values calculated for stems, roots, flowers and leaves were 1.358, $0.989,0.972$ and $0.803 \mathrm{mg} / \mathrm{mL}$, respectively ${ }^{43}$. Another study carried out by S. Asha and coworkers reported significant antioxidant activity for E. hirta. They showed antioxidant activities for three types of extractions from E. hirta through superoxide, DPPH and hydroxyl radical scavenging assays. Out of the three extracts (ethanolic, methanolic and aqueous), the ethanolic extract exhibited the highest antioxidant propensity with a significant $\mathrm{IC}_{50}$ value compared to the methanolic and aqueous extracts. Furthermore, a significant relationship was obtained between the phenolic content of the extracts and antioxidant activity, and the ethanolic extract showed a high phenolic content ${ }^{44}$. E. hirta showed maximum free radical scavenging and antioxidant activities at approximately $0.25 \mathrm{mg} / \mathrm{ml}$.

\section{Anticancer activity}

Several traditionally used medicinal plants are thought to have preventive effects against different human malignancies, including cancer. These plants are rich in chemical contents that show modulatory effects on different physiological functions and target the proliferation of cancer cells. E. hirta has been reported to produce significant anticancer effects in vitro against acute myeloid leukemia HL-60 cells $^{45}$. Furthermore, extracts from $E$. hirta have revealed anticancer effects against squamous cell carcinoma, Hep-2 and malignant melanoma ${ }^{46,47}$. Shao-Ming Chi et al., 2012 isolated (1'R,5'R)-5(5'carboxylmethyl-2'-oxocyclopentyl)-3Z-pentenyl acetate, a cyclopentanone derivative from Euphorbia hirta. The ethanolic extract was examined for cytotoxicity against the K562 and A549 cell lines. 
The outcome of the study revealed weak cytotoxicity against A549 cells $(15.02 \pm 11.60 \%)$ and remained almost inactive against $\mathrm{K} 562$ cells $^{48}$. Sandeep et al. in 2011 evaluated the antitumor properties of $E$. hirta ${ }^{49}$. Aerial parts of E. hirta were extracted using different solvents, including chloroform, ethanol and petroleum ether, and showed positive results for the presence of alkaloids, tannins, saponins, and flavonoids. The ethanol and chloroform extracts were reported to maximize the mean survival and inhibit the growth of solid tumors in administered mice. This antitumor activity was attributed to the manifestation of flavonoids.

\section{Antimalarial and anti-asthmatic activities}

Euphorbia hirta has been reported to contain a pool of active phytochemicals that raise the medicinal value of the plant. Euphorbia hirta has been termed an "Asthma plant". It shows depressant effects on the respiratory system and reflexive effects on brochial tubes $^{32}$. Additionally, methanolic extraction from aerial parts of Euphorbia hirta by bioassay-guided fractionation has been evaluated for antiparasitic activity against $P$. falciparum. The key chromatographic fraction has been reported to show over $90 \%$ inhibition at $5 \mu \mathrm{g} / \mathrm{ml}$ against $P$. falciparum ${ }^{\mathbf{5 0}}$. 
Table 2: List of some of the common medicinal and aromatic plants with potential antiviral properties ${ }^{51}$

\begin{tabular}{|c|c|c|c|c|}
\hline Family & Plant Species & Mode of Action & Plant Part & Origin \\
\hline Acanthaceae & Andrographis paniculata & Antiviral & Leaves & India, Sri Lanka \\
\hline Acanthaceae & Strobilanthes cusia & $\begin{array}{l}\text { Inhibits } \mathrm{HCoV} \text {-NL63 via tryptanthrin; anti-influenza } \\
\text { virus activity; anti-inflammatory potential }\end{array}$ & Leaves, Whole plant & Tropical Asia, Madagascar \\
\hline Adoxaceae & Sambucus nigra & $\begin{array}{l}\text { Antiviral activity against HIV, HSV, influenza, hepatitis, } \\
\text { and coxsackievirus }\end{array}$ & Whole plant & Europe and North America \\
\hline Adoxaceae & Viburnum opulus & Immunomodulation; anti-inflammatory effects & Fruits & $\begin{array}{l}\text { Western and eastern, } \\
\text { Siberia Eastern Europe, } \\
\text { Caucasus, and Central Asia }\end{array}$ \\
\hline Alliaceae & Allium sativum & Inhibits avian coronavirus; antiviral, fungistatic & Bulb & Central Asia, Iran \\
\hline Anacardiaceae & Rhus coriaria & Antiviral potential & Fruit & $\begin{array}{l}\text { Mild Mediterranean cli- } \\
\text { mates of western Asia and } \\
\text { southern Europe }\end{array}$ \\
\hline Apiaceae & Ferula assa-foetida & $\begin{array}{l}\text { Antiviral activity; great potency against } \mathrm{H} 1 \mathrm{~N} 1 \text {; anti- } \\
\text { inflammatory }\end{array}$ & Oleo-Gum-resin & Iran, Afghanistan \\
\hline Apiaceae & Saposhnikovia divaricata & High antiviral activity against PEDV corona-virus & Whole plant & China \\
\hline Apocynaceae & Aspidosperma sp. & $\begin{array}{l}\text { Antiviral activity against avian metapneumovirus and } \\
\text { other groups }\end{array}$ & Whole plant & South America \\
\hline Apocynaceae & Gymnema sylvestre & Inhibition of viral DNA synthesis; immunomodulation & Leaves, Whole plant & Asia, Africa, Australia \\
\hline Araliaceae & Oplopanax elatus & Immunomodulation and anti-inflammatory activities & Whole plant & $\begin{array}{l}\text { North America, northeast- } \\
\text { ern Asia }\end{array}$ \\
\hline Asteraceae & Anthemis hyalina & $\begin{array}{l}\text { Inhibits coronavirus replication and expression of tran- } \\
\text { sient receptor potential gene family }\end{array}$ & Whole plant & $\begin{array}{l}\text { Mediterranean region, } \\
\text { south-west Asia to Iran }\end{array}$ \\
\hline Asteraceae & $\begin{array}{l}\text { Artemisia sp. (Artemisia } \\
\text { absinthium) }\end{array}$ & $\begin{array}{l}\text { Reduces coronavirus replication; antibacterial, anti- } \\
\text { inflammatory }\end{array}$ & Whole plant & $\begin{array}{l}\text { Eurasia, north Africa, } \\
\text { North America }\end{array}$ \\
\hline Asteraceae & Cichorium intybus & $\begin{array}{l}\text { Immunomodulation; antiviral action against aden- } \\
\text { ovirus type and 5HSV-1 }\end{array}$ & Whole plant, Roots & $\begin{array}{l}\text { Eurasia, Mediterranean re- } \\
\text { gion }\end{array}$ \\
\hline Asteraceae & Cynara scolymus & ACE inhibitor, antiviral & Flower heads & Mediterranean region \\
\hline
\end{tabular}




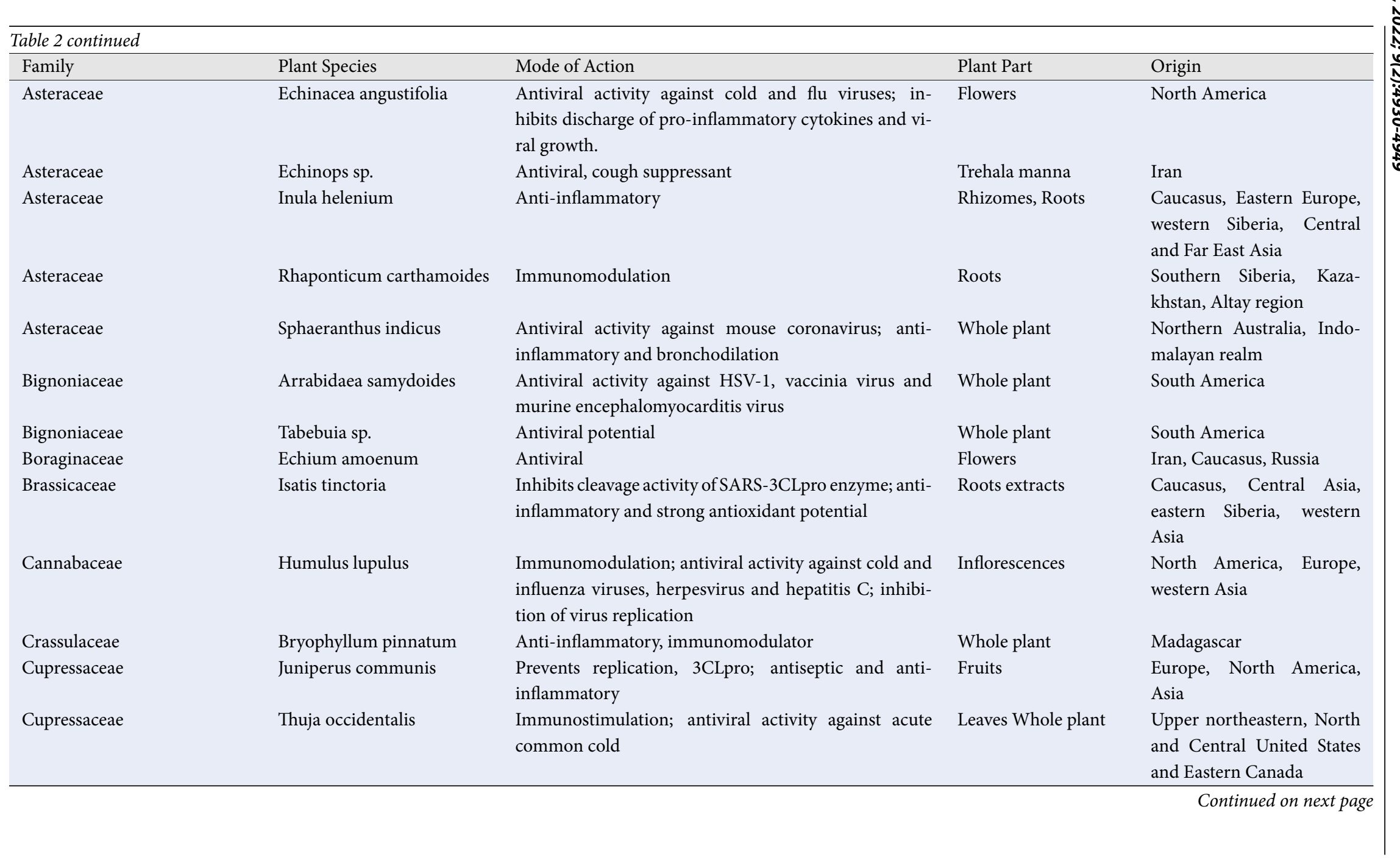




\begin{tabular}{|c|c|c|c|c|}
\hline \multicolumn{5}{|l|}{ Table 2 continued } \\
\hline Family & Plant Species & Mode of Action & Plant Part & Origin \\
\hline Elaeagnaceae & Hippophae rhamnoides & Anti-influenza activities and Immunomodulation & Fruits & $\begin{array}{l}\text { Cold-temperate regions of } \\
\text { Europe and Asia }\end{array}$ \\
\hline Euphorbiaceae & Euphorbia sp. & $\begin{array}{l}\text { Antiviral activity against SIVmac251, HSV-2, HIV-1 } \\
\text { and HIV-2 }\end{array}$ & Roots & $\begin{array}{l}\text { North and South America, } \\
\text { Southern Africa and Mada- } \\
\text { gascar, Mediterranean re- } \\
\text { gion }\end{array}$ \\
\hline Fabaceae & Acacia nilotica & Inhibits HIV protease; cytotoxic and antiviral & Whole plant & $\begin{array}{l}\text { Indian subcontinent, Mid- } \\
\text { dle East and Africa }\end{array}$ \\
\hline Fabaceae & Alhagi maurorum & $\begin{array}{l}\text { Inhibits influenza and cold viruses; relieves cough, pec- } \\
\text { toral aches, fever, vomiting and thirst }\end{array}$ & Gum tragacanth & $\begin{array}{l}\text { South-east Europe, south- } \\
\text { west Asia }\end{array}$ \\
\hline Fabaceae & Clitoria ternatea & Antiviral & Whole plant & $\begin{array}{l}\text { Indian subcontinent, } \\
\text { Southeast Asia }\end{array}$ \\
\hline Fabaceae & Desmodium canadense & High antiviral activity toward coronaviruses & Whole plant & North America \\
\hline Fabaceae & Glycyrrhiza glabra & $\begin{array}{l}\text { Immunomodulation; antiviral activity against human } \\
\text { cytomegalo-virus, Epstein-Barr virus, HSV-1, and } \\
\text { RNA viruses including H1N1, influenza A, and H5N1 }\end{array}$ & Roots & $\begin{array}{l}\text { Mediterranean area, Iran- } \\
\text { Turan, Azerbaijan }\end{array}$ \\
\hline Geraniaceae & Pelargonium sidoides & $\begin{array}{l}\text { Decreases rhinovirus infection through regulation of } \\
\text { binding viral proteins in bronchial cells. }\end{array}$ & Leaves, Whole plant & South Africa \\
\hline Hypericaceae & Hypericum connatum & High antiviral activity & Whole plant & $\begin{array}{l}\text { North America, eastern } \\
\text { Asia }\end{array}$ \\
\hline Lamiaceae & Mentha piperita & High antiviral activity against coronavirus group & Whole plant & Europe, Middle East \\
\hline Lamiaceae & Mosla sp. & Anti-influenza activity & Whole plant & $\begin{array}{l}\text { Eastern and southeastern } \\
\text { Asia, Himalayas }\end{array}$ \\
\hline Lamiaceae & $\begin{array}{l}\text { Ocimum kilimandschar- } \\
\text { icum }\end{array}$ & Antiviral activity against HIV-1, SARS-CoV-2 & Whole plant & $\begin{array}{l}\text { Central Africa, Southeast } \\
\text { Asia }\end{array}$ \\
\hline Lamiaceae & Origanum vulgare & Respiratory and antiviral activity & Leaves, Stems & $\begin{array}{l}\text { Mediterranean region, } \\
\text { Southwestern and Western } \\
\text { Eurasia }\end{array}$ \\
\hline
\end{tabular}




\begin{tabular}{|c|c|c|c|c|}
\hline \multicolumn{5}{|l|}{ Table 2 continued } \\
\hline Family & Plant Species & Mode of Action & Plant Part & Origin \\
\hline Lamiaceae & Rosmarinus officinalis & $\begin{array}{l}\text { Antiviral activity against human respiratory syncytial } \\
\text { virus; immunomodu-lator; anti-inflammatory }\end{array}$ & Whole plant & Mediterranean region \\
\hline Lamiaceae & Salvia officinalis & $\begin{array}{l}\text { High binding to COVID-19 proteases; Inhibits HSV-1 } \\
\text { and SARS-CoV replication }\end{array}$ & Whole plant & Mediterranean basin \\
\hline Lamiaceae & Scutellaria baicalensis & Inhibit nsP13 by affecting the ATPase activity & Roots & $\begin{array}{l}\text { China, Korea, Mongolia, } \\
\text { Russian far east, Siberia }\end{array}$ \\
\hline Lamiaceae & Stachys schtschegleevii & Antiviral, anti-inflammatory and anti-SARS-CoV-2 & Leaves & Iran \\
\hline Lamiaceae & Thymus vulgaris & $\begin{array}{l}\text { High antiviral activity toward coronaviruses; antioxi- } \\
\text { dant effects }\end{array}$ & Whole plant & Southern Europe \\
\hline Lauraceae & Cinnamomum cassia & $\begin{array}{l}\text { Antiviral, anti-inflammatory; inhibits attachment of } \\
\text { human respiratory syncytial virus }\end{array}$ & Bark & $\begin{array}{l}\text { Vietnam and eastern } \mathrm{Hi}- \\
\text { malayas, China }\end{array}$ \\
\hline Lythraceae & Punica granatum & $\begin{array}{l}\text { Inhibits viral glycoproteins; antiviral action against in- } \\
\text { fluenza virus and HSV-1 }\end{array}$ & Fruits, Peel, Seeds & $\begin{array}{l}\text { Iran to northern India, } \\
\text { Mediterranean region }\end{array}$ \\
\hline Malvaceae & Althaea officinalis & $\begin{array}{l}\text { Anti-inflammatory in diseases of the upper respiratory } \\
\text { tract; antitussive, chest emollient, immuno-modulator, } \\
\text { antiviral }\end{array}$ & Whole plant & $\begin{array}{l}\text { Western palearctic, boreal } \\
\text { area, Europe, Asia and } \\
\text { Africa }\end{array}$ \\
\hline Malvaceae & Firmiana simplex & $\begin{array}{l}\text { Immunomodulation; general tonic and adaptogenic } \\
\text { drug }\end{array}$ & Leaves & $\begin{array}{l}\text { South Japan, China and In- } \\
\text { donesia }\end{array}$ \\
\hline Menispermaceae & Stephania tetrandra & $\begin{array}{l}\text { Inhibits expression of } \mathrm{HCoV}-\mathrm{OC} 43 \text { nucleocapsid and } \\
\text { spike proteins; anticancer and immunomodulatory po- } \\
\text { tential }\end{array}$ & Roots & China, Taiwan \\
\hline Plantaginaceae & Plantago major & $\begin{array}{l}\text { Anti-inflammatory; antiviral activity against her- } \\
\text { pesviruses and adenoviruses }\end{array}$ & Leaves, Whole plant & $\begin{array}{l}\text { Europe, Northern and cen- } \\
\text { tral Asia }\end{array}$ \\
\hline Ranunculaceae & Nigella sativa & $\begin{array}{l}\text { Antiviral activity against avian influenza virus } \\
\text { (H9N2), Immunomodulator, broncho-dilator and } \\
\text { anti-inflammatory agent }\end{array}$ & Whole plant & $\begin{array}{l}\text { Eastern Mediterranean, } \\
\text { northern Africa, Indian } \\
\text { Subcontinent, western Asia }\end{array}$ \\
\hline Rhamnaceae & $\begin{array}{l}\text { Ampelozizyphus amazoni- } \\
\text { cus }\end{array}$ & Immunomodulation, anti-inflammatory & Whole plant & South America \\
\hline
\end{tabular}




\begin{tabular}{|c|c|c|c|c|}
\hline \multicolumn{5}{|l|}{ Table 2 continued } \\
\hline Family & Plant Species & Mode of Action & Plant Part & Origin \\
\hline Rhamnaceae & Ziziphus jujuba & $\begin{array}{l}\text { Antiviral activity; potential therapeutic agent for treat- } \\
\text { ing influenza }\end{array}$ & Fruit & $\begin{array}{ll}\text { Southeastern Europe to } \\
\text { China }\end{array}$ \\
\hline Rosaceae & Rubus sp. & Antiviral effect against human influenza virus & Fruits, Flowers & $\begin{array}{l}\text { Forest-steppe zones of } \\
\text { Eurasia }\end{array}$ \\
\hline Rosaceae & Rosa sp. & $\begin{array}{l}\text { Immunomodulatory effects; antiviral activity against } \\
\text { HIV and HSV }\end{array}$ & $\begin{array}{l}\text { Completely matured } \\
\text { fruits }\end{array}$ & $\begin{array}{l}\text { Europe, North America, } \\
\text { Northwestern Africa }\end{array}$ \\
\hline Rutaceae & Citrus trifoliata & Antiviral against oseltamivir-resistant influenza virus & Seeds & Northern China and Korea \\
\hline Sapindaceae & Litchi chinensis & $\begin{array}{l}\text { The plant inhibit SARS-3CLpro, while the isolated ter- } \\
\text { penoids suppress HIV-1 protease }\end{array}$ & Seeds & Southeastern China \\
\hline Saururaceae & Houttuynia cordata & $\begin{array}{l}\text { Inhibits viral tRNA polymerase (RdRp) and SARS- } \\
\text { 3CLpro activity; activates IL- } 2 \text { and IL-10 secretion }\end{array}$ & Whole plant & Southern Asia \\
\hline Solanaceae & Hyoscyamus niger & $\begin{array}{l}\text { Viral inhibition; bronchodilator; antiviral effect against } \\
\text { human influenza virus A/WSN/33 }\end{array}$ & Whole plant & $\begin{array}{l}\text { Middle East, Asia, Conti- } \\
\text { nental Europe }\end{array}$ \\
\hline Theaceae & Camellia japonica & $\begin{array}{l}\text { Strong inhibition of a member of coronavirus family } \\
\text { that is porcine epidemic diarrhea virus through sup- } \\
\text { pression of important protein and gene synthesis during } \\
\text { replication }\end{array}$ & Whole plant, Flowers & East Asia \\
\hline Urticaceae & Urtica dioica & Inhibition of SARS coronavirus replication & Leaves & $\begin{array}{l}\text { Europe, temperate Asia, } \\
\text { and western North Africa }\end{array}$ \\
\hline Verbenaceae & Vitex trifolia & $\begin{array}{l}\text { Strongly antiviral against and mouse coronavirus HSV, } \\
\text { anti-inflammatory effects on lungs, immunomodula- } \\
\text { tory }\end{array}$ & Whole plant & $\begin{array}{l}\text { French Polynesia, Tropical } \\
\text { East Africa }\end{array}$ \\
\hline Zingiberaceae & Zingiber officinale & Inhibition of syncytial virus effecting human respiratory & Rhizome & Asia, Maritime Southeast \\
\hline Zosteraceae & Zostera marina & Strongly antiviral against influenza $A$ virus & Whole plant & $\begin{array}{l}\text { North America, Europe, } \\
\text { Asia }\end{array}$ \\
\hline
\end{tabular}




\section{Antiviral activity of Euphorbia hirta}

Medicinal and aromatic plants have been a rich reserve for antiviral agents since time immemorial. Some of the medicinal plants with antiviral activity are listed in Table 2. Euphorbia hirta is a medicinally as well as biologically important plant. It has been used to treat a wide variety of disorders since time immemorial ${ }^{52}$. Euphorbia hirta has been a foremost important constituent of traditional systems of medicines, including Ayurveda medicine and TCM. It is used for the management of respiratory diseases, gastrointestinal disorders, venereal diseases, sterility, menstrual problems, kidney stones, colds, coughs, emphysema, laryngeal spasms, hay fever, bronchitis, asthma, amoebic dysentery, vomiting, heartburn, peptic ulcers, diarrhea, and intestinal parasites ${ }^{53-58}$. Gyuris et al. evaluated the Euphorbia hirta extract for its antiretroviral potency against $\mathrm{T}$ lymphocyte MT4 cells. The effects of aqueous and methanolic extracts of the plant on replication of human immunodeficiency virus-1 (HIV-1), simian immunodeficiency virus SIVmac251 and HIV-2 were determined. The results supported the remarkable antiviral activity of both fractions against all three viruses ${ }^{59}$. Moreover, the methanolic extract of Euphorbia hirta showed more efficacy than the aqueous extract.

In another study, the role of Euphorbia hirta against dengue was demonstrated. Dengue disease is a viral disease caused by four distinct serotypic members of the family Flaviviridae and genus Flavivirus, including DENV 1-4 ${ }^{60}$. The Euphorbia hirta plant has been regarded as a game changer in dengue management. Clinical investigation of Euphorbia hirta has been recorded against age group 30 - 35, which after the supplementation revealed an approximately $70 \%$ reduction in flu-like symptoms caused by dengue ${ }^{\mathbf{6 1}}$. The in vitro analysis of the ethanolic extract of the plant showed remarkable inhibition of plaque formation up to $85 \%$ and $34.7 \%$ against DENV-1 and DENV-2 ${ }^{62}$, respectively. Some of the studies that have been carried out for the calculation of the antidengue property of Euphorbia hirta are listed in Table 3 . 
Table 3: List of some of the research investigations performed on the anti-dengue potential of $E$. hirta

\begin{tabular}{|c|c|c|c|}
\hline Study & Results & Experimental model & Plant part(s)/extract \\
\hline Apostol et al. 2012 & $\begin{array}{l}\text { The administration of } E \text {. hirta continuously for } 14 \\
\text { days to rat's exhibit enhancing effects on platelet } \\
\text { count and reductive effects on clotting and bleed- } \\
\text { ing time. }\end{array}$ & $\begin{array}{l}\text { Rats induced thrombocytopenic by } \\
\text { ethanol (i.p injection) (In vivo assay } \\
\text { model) }\end{array}$ & Decoction of fresh whole plant \\
\hline Arollado et al. 2013 & $\begin{array}{l}\text { The consecutive treatment of rats with } E \text {. hirta for } \\
9 \text { days increased mean platelet count by } 80 \% \text {. }\end{array}$ & $\begin{array}{l}\text { Rats induced thrombocytopenic by } \\
\text { Anagrelide (i.p injection) (In vivo as- } \\
\text { say model) }\end{array}$ & Water extract of leaves \\
\hline Coloma et al. 2015 & $\begin{array}{l}\text { A surveillance study of questionnaire was exe- } \\
\text { cuted in Agoo, La Union, Philippines demon- } \\
\text { strated Tawa-Tawa is very high in demand against } \\
\text { dengue. } \\
\text { The thrombocytopenic rabbits fed with E. hirta } \\
\text { juice showed remarkable increase in the platelet } \\
\text { count with } 24 \text { h of time. }\end{array}$ & $\begin{array}{l}\text { Descriptive ethnobotanical survey. } \\
\text { Aspirin-induced thrombocytopenia } \\
\text { rabbits (In vivo assay model) }\end{array}$ & $\begin{array}{l}\text { Expressed juice of } E \text {. hirta. } \\
\text { Expressed juice of } E \text {. hirta }\end{array}$ \\
\hline de Guzman et al. 2016 & $\begin{array}{l}\text { The study showed very high percentage of women } \\
\text { of } 60-80 \text { years of age have remarkable pri- } \\
\text { mary and secondary knowledge of using E. hirta } \\
\text { against dengue. }\end{array}$ & Ethnopharmacological survey & Decoction of leaves or bark \\
\hline Mir et al. 2012 & $\begin{array}{l}\text { Post } 24 \text { h of } E \text {. hirta administration over } 70 \% \text { pa- } \\
\text { tients showed promising platelet increase. Pa- } \\
\text { tients showed noticeable recovery in flu and fever } \\
\text { like symptoms. }\end{array}$ & $\begin{array}{l}\text { Clinical study, Sir Ganga Ram Hos- } \\
\text { pital, Lahore using on admitted } \\
\text { dengue patients. }\end{array}$ & Herbal water \\
\hline Saptawati et al. 2017 & Virus inhibition by $34.7 \%$ & In vitro assay for DENV-2 serotype & Ethanol extract of leaves \\
\hline Siva Ganesh et al. 2015 & $\begin{array}{l}\text { Quercetin molecule has been reported to possess } \\
\text { extraordinary binding efficacy against dengue } \\
\text { virus. The leaves of } E \text {. hirta are rich in quercetin } \\
\text { and thus effective against dengue virus. }\end{array}$ & $\begin{array}{l}\text { Molecular docking study using phy- } \\
\text { tochemicals with } 2 \mathrm{P} 40 \text {-methyl trans- } \\
\text { ferase, and } 2 \text { FOM-dengue proteases } \\
\text { of dengue }\end{array}$ & Leaves \\
\hline
\end{tabular}




\begin{tabular}{|c|c|c|c|}
\hline \multicolumn{4}{|l|}{ Table 3 continued } \\
\hline Study & Results & Experimental model & Plant part(s)/extract \\
\hline Tayone et al. 2014 & $\begin{array}{l}\text { Ethyl acetate fraction of dichloromethane and } \\
\text { methanolic extracts of E. hirta inhibit the plaque } \\
\text { formation by } 85 \% \text { in dengue virus serotype- } 1 \text {. } \\
\text { The extract fraction resulted in the identification } \\
\text { and isolation of Nine compounds. }\end{array}$ & In vitro assay & $\begin{array}{l}\text { Ethyl acetate/methanol and ethyl acetate } \\
\text { partitioning and tea of E. hirta. }\end{array}$ \\
\hline
\end{tabular}


Furthermore, Euphorbia hirta has been reported to have evident antiviral potency against herpes, coxsackie and polioviruses. Euphorbia hirta has also been reported to have selective antiviral activity against HSV-1 with an MIC value of $0.1 \mathrm{mg} / \mathrm{ml}^{63}$. The leaf extract of Euphorbia hirta plant has been reported to impart protective cover against potato virus $\mathrm{X}$ in both systemic and hypersensitive hosts. The active constituent actinomycin D was systemically sensitive toward the virus $\mathrm{X}^{64}$.

\section{POSSIBLE ROLE OF EUPHORBIA HIRTA AGAINST SARS-COV-2}

Unfortunately, communicability and COVID-19 infection are growing rapidly each day, causing huge human and economic losses globally ${ }^{65}$. The common clinical symptoms identified among COVID-19 patients include cough, shortness of breath, fever, and respiratory symptoms (such as inflammation caused by allergy to the pathogen). Euphorbia hirta is an important medicinal plant involved in the global traditional medicine core, including Ayurvedic medicine and Traditional Chinese Medicine ${ }^{\mathbf{6 6}}$. The lyophilized aqueous extract of $E$. hirta revealed potential antipyretic, anti-inflammatory and analgesic actions in xenografted mice and rat models. The antipyretic effects of Euphorbia hirta were evaluated via yeastinduced hyperthermia and showed potential activity at $100-400 \mathrm{mg} / \mathrm{kg}^{67}$. Furthermore, writhing and hot plate tests showed anti-analgesic activity in a dosedependent manner at $20 \mathrm{mg} / \mathrm{kg}$ and $25 \mathrm{mg} / \mathrm{kg}$, respectively. Additionally, strong anti-inflammatory activity of E. hirta was observed in carrageenan-induced edema test rats at $100 \mathrm{mg} / \mathrm{kg}^{68}$. A clinical study in dengue patients performed by S. D Pareera et al. at Sir Ganga Ram Hospital Lahore revealed that the administration of an aqueous extract of E. hirta orally enhanced the total leucocyte count and platelets in patients aged 30-55 years. Moreover, $70 \%$ of the patients showed a response of lowering flu symptoms and fever. Moreover, the ethanolic extract of Euphorbia hirta demonstrated significant inhibition of dengue virus stereotypes 1 and $2^{69}$. Euphorbia hirta is also known as an asthma plant and possesses remarkable activity against asthma ${ }^{70}$. Diarrhea is a key symptom commonly identified in COVID-19 patients. Euphorbia hirta plant has been used against several gastrointestinal disorders, including diarrhea and ulcers. The methanolic extract of Euphorbia hirta has been identified with rich flavonol glucoside content, including afzelin, myrcitrin and quercitin. The antimicrobial analysis of these compounds yielded $\mathrm{IC}_{50}$ values of 1.1, 5.4 and 4.1 against malarial parasites, respectively ${ }^{51}$. Furthermore, the plant Euphorbia hirta has been reported to have high free radical scavenging properties. The maximum DPPH scavenging activity was reported by leaves, followed by flowers, roots and stems $(72.96 \pm 0.78 \%, 52.45 \pm 0.66 \%$, $48.59 \pm 0.97 \%$, and $44.42 \pm 0.94 \%)^{71}$. Furthermore, Euphorbia hirta has been reported to induce potential nonspecific immune responses, such as phagocytic ratio and lysozyme activity, in an Aeromonas hydrophila pathogen-infected fish model ${ }^{72}$. At higher concentrations, the plant was successful in eliminating Aeromonas hydrophila from the kidney and blood and enhanced the numbers of WBCs, RBCs and hemoglobin in test fish. Additionally, E. hirta leaf extract enhanced the fabrication of $\log _{2}$ antibodies ${ }^{73}$. Euphorbia hirta also showed potential immunomodulatory effects against animal models. The maximum inhibition was recorded at 100 and $200 \mathrm{mg} / \mathrm{kg}$, wherein it remarkably blocks the generation of cellmediated immune responses (IL-2, TNF- $\alpha$, IFN- $\gamma$, $\mathrm{CD}^{+}, \mathrm{CD}^{+}$and $\left.\mathrm{CD} 8^{+}\right)^{74}$.

SARS-CoV-2 attaches to the host cell using the receptor-binding domain (RBD) in its spike protein ${ }^{75}$. The RBD recognizes the ACE2 binding ridge on the outer cell membrane of the host cell, which leads to smooth entrance. The SARS-CoV-2 RBD bears an ACE2-binding ridge with a more compact conformation. Moreover, two virus-binding hotspots at the RBD-ACE2 interface are stabilized by several residue changes. The methanolic extract of $\mathrm{Eu}$ phorbia hirta roots and leaves has been reported to possess substantial angiotensin converting enzyme (ACE) anti-dipsogenic and inhibition activities. The extract suppressed the activity of ACE $50 \%$ at $160 \mu \mathrm{g}$ and $90 \%$ at $500 \mu \mathrm{g}^{76}$. The possible inhibition of the interface between SARS-CoV-2 and human host cells is shown in Figure 5.

\section{FUTURE PROSPECTS}

It is essential and needed of this era to continue the expansion of drug development and therapeutics based on plants and their chemical composition. Drugs and therapeutics based on plants are economical (cost effective) and are believed to be less toxic than synthetics. Cancer is a global health problem, making it difficult for scientists and researchers to overcome this ailment. Plants have assisted humanity against several malignancies in the past, and they are believed to do so currently and in the future as well. There are several drugs based on plants that have been approved for cancer chemotherapy, such as Taxol and paclitaxel. Euphorbia hirta has a substantial potential to inhibit different cancers in humans due to its rich phytochemistry and active constituents. This plant 

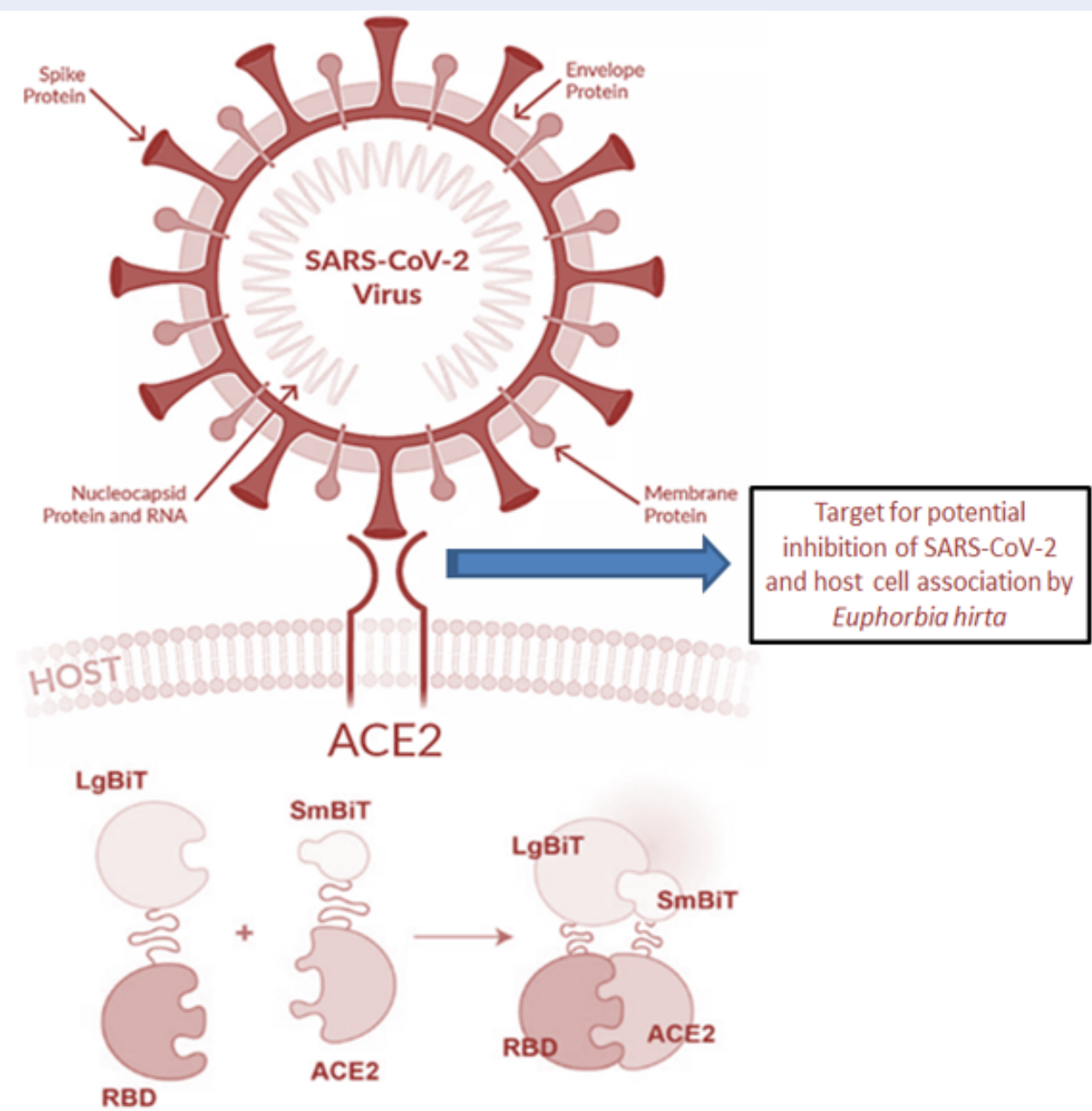

Figure 5: Target site for possible inhibition of SARS-CoV-2 entrance to host human cells. Adapted from Brown et al. $2021^{77}$.

bears a unique class of compounds called euphorbins, and they are complex in structure and active in nature. Therefore, it is believed to possess remarkable pharmacological potential, which needs to be explored. It is highly recommended to push on progress in the field of potential antiviral therapeutics designed on natural products and their synthetic derivatives. Moreover, to look for therapeutics against coronaviruses, natural products have been the leading sources that have assisted human civilization in overcoming health hazards since the ages. The therapeutics designed on natural products have significant benefits over the synthetic ones, such as their cost effectiveness and miniscule or lack of side effects. Despite noteworthy developments in the field of vaccine development in this modern era, we lag behind in terms of developing breakthrough vaccines for several viruses, including SARS-CoV-2. Therefore, it seems to be a very difficult job to develop a potential treatment methodology for the management of such infectious viral diseases. However, plants such as Euphorbia hirta and their bioactive phytochemicals have tremendous potential to serve humanity in overcoming these infectious diseases. Based on docking studies and the antiviral properties of phytochemicals, E. hirta could also prove advantageous against coronaviruses. The rapid genomic mutations in SARSCoV-2, HIV and HSV are the key drawbacks of antiviral therapeutics in targeting specific proteins and genes. The plant Euphorbia hirta has huge potential against COVID-19, as it showed against different viruses, such as malaria, HSV and dengue. The plant has a strong antiviral property and has significant potential to target key sites, enzymes and replication of SARS-COV-2. Therefore, we recommend clinical in- 
vestigations of Euphorbia hirta against this lethal disease.

\section{CONCLUSIONS}

Euphorbia hirta is a valuable medicinal plant used globally in different traditional systems of medicines. It has been reported to have various bioactivities against a wide array of human disorders. Most importantly, the plant as a whole bears a huge variety of chemical entities that enhance its therapeutic potential. The plant as a whole has been shown to have remarkable antiviral potential against HIV, DANV, HSV, etc. and enhancing immune responses against pathogens. It has great potency for free radical scavenging and ACE inhibition. Therefore, these features of Euphorbia hirta may play an advantageous role throughout the management of highly infectious and deadly viral diseases such as COVID-19.

\section{ABBREVIATIONS}

SARS-CoV-2: Severe Acute Respiratory Syndrome Corona Virus-2, ACE: Angiotensin-converting enzyme, ABTS: 2,2'-azino-bis(3-ethylbenzothiazoline6-sulfonic acid, CD: Cluster of differentiation, COVID-19: Corona Virus Disease 2019, DPPH: 2,2-diphenyl-1-picrylhydrazyl, DENV: Dengue Virus, HSV: Herpes Simplex Virus, HIV: Human Immunodeficiency Virus, IL-2: Interleukin-2, IFN- $\gamma$ : Interferon gamma, MIC: Minimum inhibitory concentration, RBC: Red Blood cells, RBD: Receptor Binding Domain, WBC: White Blood Cells, TCM: Traditional Chinese Medicine, TNF- $\alpha$ : Tumor Necrosis Factor Alpha

\section{ACKNOWLEDGMENTS}

Aadil Khursheed is highly thankful to Dr. Vikrant Jain and the whole Department of Chemistry, Madhyanchal Professional University, for providing academic guidance and platform.

\section{AUTHOR'S CONTRIBUTIONS}

All authors equally contributed to this work, read and approved the final manuscript.

\section{FUNDING}

None.

\section{AVAILABILITY OF DATA AND MATERIALS}

Not applicable.

\section{ETHICS APPROVAL AND CONSENT TO PARTICIPATE}

Not applicable.

\section{CONSENT FOR PUBLICATION}

Not applicable.

\section{COMPETING INTERESTS}

The authors declare that they have no competing interests.

\section{REFERENCES}

1. Patel SB, Naikwade NS, Magdum CS. Review on Phytochemistry and Pharmacological Aspects of Euphorbia hirta Linn. Asian J Pharm Res Health Care. 2009;1(1):113-33.

2. Hazra K, Dutta S, Ghosal S, Paria D, Rao MM. Phytopharmacognostic evaluation of plant Euphorbia hirta L. International Journal of Hospitality Management. 2019;7(3):7-15.

3. Gagliardi KB, Rosado A, Souza LA, Moscheta IS, Albiero AL. Structure and development of fruits and seeds of weed species of Euphorbiaceae. Acta Botanica Brasilica. 2012;26(1):38-45. Available from: 10.1590/S010233062012000100005.

4. Sultana RS. Anatomical Characteristics of Stem and Leaf in Euphorbia hirta L. Plant. 2017;5(1):9-12. Available from: 10. 11648/j.plant.20170501.12.

5. Acharya D, Vaidya M. Anatomical study of Euphorbia hirta L. World Journal of Pharmaceutical Research. 2017;6(7):140716.

6. Gupta N, Vishnoi G, Wal A, Wal P. Medicinal value of Euphorbia tirucalli. Sys Rev Pharm. 2013;4(1):40. Available from: 10.4103/ 0975-8453.135843.

7. Li LQ, Huang T, Wang YQ, Wang ZP, Liang Y, Huang TB. COVID19 patients' clinical characteristics, discharge rate, and fatality rate of meta-analysis. Journal of Medical Virology. 2020;92(6):577-83. PMID: 32162702. Available from: 10.1002/ jmv. 25757.

8. Xu J, Zhang Y. Traditional Chinese Medicine treatment of COVID-19. Complementary Therapies in Clinical Practice. 2020;39:101165. PMID: 32379692. Available from: 10.1016/ j.ctcp.2020.101165.

9. Ho LT, Chan KK, Chung VC, Leung TH. Highlights of traditional Chinese medicine frontline expert advice in the China national guideline for COVID-19. European Journal of Integrative Medicine. 2020;36:101116. PMID: 32292529. Available from: 10.1016/j.eujim.2020.101116.

10. Ni L, Chen L, Huang X, Han C, Xu J, Zhang H. Combating COVID-19 with integrated traditional Chinese and Western medicine in China. Acta Pharmaceutica Sinica B. 2020;10(7):1149-62. PMID: 32834946. Available from: 10. 1016/j.apsb.2020.06.009.

11. Ang L, Lee HW, Choi JY, Zhang J, Lee MS. Herbal medicine and pattern identification for treating COVID-19: a rapid review of guidelines. Integrative Medicine Research. 2020;9(2):100407. PMID: 32289016. Available from: 10.1016/j.imr.2020.100407.

12. Wani AR, Yadav K, Khursheed A, Rather MA. An updated and comprehensive review of the antiviral potential of essential oils and their chemical constituents with special focus on their mechanism of action against various influenza and coronaviruses. Microbial Pathogenesis. 2021;152:104620. PMID: 33212200. Available from: 10.1016/j.micpath.2020.104620.

13. Al-Snafi AE. Pharmacology and therapeutic potential of euphorbia hirta (syn: euphorbia pilulifera)- a review. IOSR Journal of Pharmacy. 2017;7(3):7-20. Available from: 10.9790/ 3013-0703010720.

14. Panzu PZ, Inkoto CL, Ngbolua KN, Mukeba FB, Kitadi JM, Taba $\mathrm{K}$. Review on the phytochemistry, toxicology and bioactivities of Euphorbia hirta L. A potential antisickling medicinal plant species. J Med Plant Herb Ther Res. 2020;7:8-18. 
15. Srivastava R, Soni N. An updated review on phytopharmacological profile of Euphorbia tithymaloides L. Journal of Pharmaceutical Innovation. 2019;8:109-15.

16. Ghosh P, Das P, Mukherjee R, Banik S, Karmakar S, Chatterjee S. Extraction and quantification of pigments from Indian traditional medicinal plants: A comparative study between tree, shrub, and herb. International Journal of Pharmaceutical Sciences and Research. 2018;9(7):3052-9.

17. Kausar J, Muthumani D, Hedina A, S S, Anand V. Sivasamy and Anand $\mathrm{V}$ : review of the phytochemical and pharmacological activities of Euphorbia hirta Linn. Pharmacognosy Journal. 2016;8(4):310-3. Available from: 10.5530/pj.2016.4.2.

18. Mohammad AB, Mohammad SH, Mohammad A, Siddika R, Sultana S, Islam RB. Euphorbia hirta Linn. a wonderful miracle plant of mediterranean region: a review. Journal of Medicinal Plant Studies. 2017;5(3):170-5.

19. Ghosh P, Ghosh C, Das S, Das C, Mandal S, Chatterjee S. Botanical description, phytochemical constituents and pharmacological properties of Euphorbia hirta Linn. A review. International Journal of Health Sciences and Research. 2019;9(3):273-86.

20. Khursheed A, Jain V. Phytochemical screening, antioxidant, and antimicrobial activity of different Portulaca oleracea $L$. extracts growing in Kashmir Valley. Journal of Biochemical Technology. 2021;12(3):1-8. Available from: 10.51847/ SFpNn91fUX.

21. Khursheed A, Rather MA, Rashid R. Plant-based natural compounds and herbal extracts as promising apoptotic agents: their implications for cancer prevention and treatment. Adv Biomed Pharma. 2016;3(04):245-69. Available from: 10.19046/ abp.v03i04.08.

22. Suresh K. Antimicrobial and Phytochemical Investigation of the Leaves of Carica papaya L., Cynodon dactylon (L.) Pers., Euphorbia hirta L., Melia azedarach L. and Psidium guajava L. Ethnobotanical Leaflets. 2008;12:1184-1191.

23. Igwe KK, Madubuike AJ, Akomas SC, Otuokere IE, Ukwueze CS. Studies of the medicinal plant Euphorbia hirta methanol leaf extract phytocomponents by GCMS analysis. Int J Sci Tech Res Eng. 2016;1(4):9-16.

24. Chen L. [Polyphenols from leaves of Euphorbia hirta L]. Zhongguo Zhongyao Zazhi. 1991;16(1):38-9. PMID: 2069701.

25. Essiett UA, Okoko Al. Comparative nutritional and phytochemical screening of the leaves and stems of AcalyphafimbriataSchum. \&amp;Thonn. and Euphorbia hirta Linn. Bull Env Pharmacol Life Sci. 2013;2(4):38-44.

26. Youssouf MS, Kaiser $P$, Tahir M, Singh GD, Singh $S$, Sharma VK. Anti-anaphylactic effect of Euphorbia hirta. Fitoterapia. 2007;78(7-8):535-9. PMID: 17643865. Available from: 10.1016/j.fitote.2007.06.003.

27. Gopi K, Renu K, Vishwanath BS, Jayaraman G. Protective effect of Euphorbia hirta and its components against snake venom induced lethality. Journal of Ethnopharmacology. 2015;165:180-90. PMID: 25727964. Available from: 10.1016/j. jep.2015.02.044.

28. Tona L, Kambu K, Ngimbi N, Mesia K, Penge O, Lusakibanza M. Antiamoebic and spasmolytic activities of extracts from some antidiarrhoeal traditional preparations used in Kinshasa, Congo. Phytomedicine. 2000;7(1):31-8. PMID: 10782488. Available from: 10.1016/S0944-7113(00)80019-7.

29. Gnecco S, Perez C, Bittner M, Silva YM. Distribution pattern of n-alkanes in Chilean species from the Euphorbiaceae family. Bol Soc Chil Quim. 1996;41:229-33.

30. Galvez J, Zarzuelo A, Crespo ME, Lorente MD, Ocete MA, Jiménez $\mathrm{J}$. Antidiarrhoeic activity of Euphorbia hirta extract and isolation of an active flavonoid constituent. Planta Medica. 1993;59(4):333-6. PMID: 8372151. Available from: 10. 1055/s-2006-959694.

31. Gálvez J, Crespo ME, Jiménez J, Suárez A, Zarzuelo A. Antidiarrhoeic activity of quercitrin in mice and rats. The Journal of Pharmacy and Pharmacology. 1993;45(2):157-9. PMID: 8095537. Available from: 10.1111/j.2042-7158.1993.tb03706.x.
32. Chopra RN, Chopra IC, Handa KL, Kapur LD. Indigenous drugs of India. Academic publishers; 1994.

33. Md RMRUF, Rahman MA. Phytochemical Screening and ExVivo Cardioprotective Assay of Euphorbia hirta (L). Cell Mol Med. 2016;2:3.

34. Sood SK, Bhardwaj R, Lakhanpal TN. Ethnic Indian Plants in cure of diabetes. Scientific publishers, 2005.

35. Singh P, Sinha KK. Inhibition of aflatoxin production on some agricultural commodities through aqueous plant extracts. Journal of the Indian Botanical Society. 1986;65:30-2.

36. Ogbulie JN, Ogueke CC, Okoli IC, Anyanwu BN. Antibacterial activities and toxicological potentials of crude ethanolic extracts of Euphorbia hirta. African Journal of Biotechnology. 2007:6:1544-8.

37. Kumari I, Pandey RK. Antibacterial Activity of Euphorbia hirta L. In Applications of Biotechnology for Sustainable Development. Springer, Singapore. 2017, pp. 1-5. Singapore. Available from: 10.1007/978-981-10-5538-6_1.

38. Rajeh MA, Zuraini Z, Sasidharan S, Latha LY, Amutha S. Assessment of Euphorbia hirta L. leaf, flower, stem and root extracts for their antibacterial and antifungal activity and brine shrimp lethality. Molecules (Basel, Switzerland). 2010;15(9):6008-18. PMID: 20877206. Available from: 10.3390/molecules 15096008.

39. Prabhat D, Suman M, Saumya P, Ranjan S, Praveen N. Pharmacological evaluation of anti-inflammatory activity of Euphorbia hirta against carrageenan induced paw edema in rats. Der Pharmacia Lettre. 2010;2(2):151-4.

40. Lanhers MC, Fleurentin J, Dorfman P, Mortier F, Pelt JM. Analgesic, antipyretic and anti-inflammatory properties of Euphorbia hirta. Planta Medica. 1991;57(3):225-31. PMID: 1896520. Available from: 10.1055/s-2006-960079.

41. Martinez V, Mariano A, Teresa OR, Lazcano ME, Bye R. Antiinflammatory active compounds from the $n$-hexane extract of Euphorbia hirta. J Mex Chem Soc. 1999;43:103-105.

42. Chen J, Er HM, Mohamed SM, Chen YS. In vitro antiinflammatory activity of fractionated Euphorbia hirta aqueous extract on rabbit synovial fibroblasts. Biomedical Journal. 2015;38(4):301-6. PMID: 25673170. Available from: 10.4103/ 2319-4170.151031.

43. Basma AA, Zakaria Z, Latha LY, Sasidharan S. Antioxidant activity and phytochemical screening of the methanol extracts of Euphorbia hirta L. Asian Pacific Journal of Tropical Medicine. 2011;4(5):386-90. PMID: 21771682. Available from: 10.1016/ S1995-7645(11)60109-0.

44. Asha S, Thirunavukkarasu P, Mani VM, Sadiq AM. Antioxidant activity of Euphorbia hirta Linn leaves extracts. European Journal of Medicinal Plants. 2016;14(1):1-4. Available from: 10.9734/EJMP/2016/24952.

45. Sharma N, Samarakoon KW, Gyawali R, Park YH, Lee SJ, Oh SJ. Evaluation of the antioxidant, anti-inflammatory, and anticancer activities of Euphorbia hirta ethanolic extract. Molecules (Basel, Switzerland). 2014;19(9):14567-81. PMID: 25225720. Available from: 10.3390/molecules190914567.

46. Vijaya K, Ananthan S, Nalini R. Antibacterial effect of theaflavin, polyphenon 60 (Camellia sinensis) and Euphorbia hirta on Shigella spp.: a cell culture study. Journal of Ethnopharmacology. 1995;49(2):115-8. PMID: 8847884. Available from: 10.1016/0378-8741(95)90039-X.

47. Sidambaram RR, Dinesh MG, Jayalakshmi ET. An in vitro study of cytotoxic activity of euphorbia hirta on hep2 cells of human epithelioma of larynx. International Journal of Pharmacy and Pharmaceutical Sciences. 2011;3:101-3.

48. Chi SM, Wang Y, Zhao Y, Pu JX, Du X, Liu JP. A new cyclopentanone derivative from Euphorbia hirta. Chemistry of Natural Compounds. 2012;48(4):577-9. Available from: 10.1007/ s10600-012-0315-0.

49. Sandeep BP, Chandrakant SM. Phytochemical investigation and antitumor activity of Euphorbia hirta Linn. European Journal of Experimental Biology. 2011;1(1):51-6.

50. Liu Y, Murakami N, Ji H, Abreu P, Zhang S. Abreu Pedro, Zhang, S. Antimalarial flavonol glycosides from Euphorbia hirta. Pharmaceutical Biology. 2007;45(4):278-81. Available from: 10. 
$1080 / 13880200701214748$

51. Liu Y, Murakami N, Ji H, Abreu P, Zhang S. Antimalarial Flavonol Glycosides from Euphorbia hirta. Pharmaceutical Biology. 2007;45(4):278-81. Available from: 10.1080/ 13880200701214748

52. Huang L, Chen S, Yang M. Euphorbia hirta (Feiyangcao): A review on its ethnopharmacology, phytochemistry and pharmacology. Journal of Medicinal Plants Research. 2012;6(39):5176-85. Available from: 10.5897/JMPR12.206.

53. Kumar S, Malhotra R, Kumar D. Euphorbia hirta: its chemistry, traditional and medicinal uses, and pharmacological activities. Pharmacognosy Reviews. 2010;4(7):58-61. PMID: 22228942. Available from: 10.4103/0973-7847.65327.

54. Johnson PB, Abdurahman EM, Tiam EA, Abdu-Aguye I, Hussaini IM. Euphorbia hirta leaf extracts increase urine output and electrolytes in rats. Journal of Ethnopharmacology 1999;65(1):63-9. PMID: 10350369. Available from: 10.1016/ S0378-8741(98)00143-3.

55. Abubakar EM. Antibacterial activity of crude extracts of Euphorbia hirta against some bacteria associated with enteric infections. Journal of Medicinal Plants Research. 2009;3(7):498-505.

56. Ekpo OE, Pretorius E. Asthma, Euphorbia hirta and its antiinflammatory properties. South African Journal of Science. 2007;103(5-6):201-3.

57. Ogunlesi M, Okiei W, Ofor E, Osibote AE. Analysis of the essential oil from the dried leaves of Euphorbia hirta Linn (Euphorbiaceae), a potential medication for asthma. African Journal of Biotechnology. 2009;8(24):1-0.

58. Gyuris A, Szlávik L, Minárovits J, Vasas A, Molnár J, Hohmann J. Antiviral activities of extracts of Euphorbia hirta L. against HIV-1, HIV-2 and SIVmac251. In Vivo (Athens, Greece). 2009;23(3):429-32. PMID: 19454510.

59. Rey FA. Dengue virus: two hosts, two structures. Nature. 2013;497(7450):443-4. PMID: 23698439. Available from: $10.1038 / 497443 \mathrm{a}$.

60. Mir M, Khurshid R, Aftab R. Management of thrombocytopenia and flu-like symptoms in dengue patients with herbal water of Euphorbia hirta. Journal of Ayub Medical College, Abbottabad. 2012;24(3-4):6-9. PMID: 24669596.

61. Perera SD, Jayawardena UA, Jayasinghe CD. Potential use of Euphorbia hirta for dengue: A systematic review of scientific evidence. J Trop Med. 2018;2018:2048530. Available from: $10.1155 / 2018 / 2048530$.

62. Sytar O, Brestic M, Hajihashemi S, Skalicky M, Kubeš J, LamillaTamayo L. COVID-19 prophylaxis efforts based on natural antiviral plant extracts and their compounds. Molecules (Basel, Switzerland). 2021;26(3):727. PMID: 33573318. Available from: 10.3390/molecules26030727.

63. Awasthi LP, Mukerjee K. Protection of potato virus $X$ infection by plant extracts. Biologia Plantarum. 1980;22(3):205-9. Available from: 10.1007/BF02892740.

64. Hamidi JA, Ismaili NH, Ahmadi FB, Lajisi NH. Antiviral and cytotoxic activities of some plants used in Malaysian indigenous medicine. Pertanika Journal of Tropical Agricultural Science. 1996;19(2/3):129-36.

65. Haleem A, Javaid M, Vaishya R, Deshmukh SG. Areas of academic research with the impact of COVID-19. The American
Journal of Emergency Medicine. 2020;38(7):1524-6. PMID: 32317202. Available from: 10.1016/j.ajem.2020.04.022.

66. Cheng HY, Huang HH, Yang CM, Lin LT, Lin CC. The in vitro antiherpes simplex virus type- 1 and type- 2 activity of Long Dan Xie Gan Tan, a prescription of traditional Chinese medicine. Chemotherapy. 2008;54(2):77-83. PMID: 18332627. Available from: $10.1159 / 000119705$.

67. Lanhers MC, Fleurentin J, Dorfman P, Mortier F, Pelt JM. Analgesic, antipyretic and anti-inflammatory properties of Euphorbia hirta. Planta Medica. 1991;57(3):225-31. PMID: 1896520. Available from: $10.1055 / \mathrm{s}-2006-960079$.

68. Prabhat D, Suman M, Saumya P, Ranjan S, Praveen N. Pharmacological evaluation of anti-inflammatory activity of Euphorbia hirta against carrageenan induced paw edema in rats. Der Pharmacia Lettre. 2010;2(2):151-4.

69. Tayone WC, Tayone JC, Hashimoto M. Isolation and structure elucidation of potential Anti-Dengue metabolites from TawaTawa (Euphorbia hirta Linn.). Walailak Journal of Science and Technology. 2014;11(10):825-32.

70. Ekpo OE, Pretorius E. Asthma, Euphorbia hirta and its antiinflammatory properties. South African Journal of Science. 2007;103(5-6):201-3.

71. Basma AA, Zakaria Z, Latha LY, Sasidharan S. Antioxidant activity and phytochemical screening of the methanol extracts of Euphorbia hirta L. Asian Pacific Journal of Tropical Medicine. 2011:4(5):386-90. PMID: 21771682. Available from: 10.1016/ S1995-7645(11)60109-0.

72. Pratheepa V, Sukumaran N. Effect of Euphorbia hirta plant leaf extract on immunostimulant response of Aeromonas hy drophila infected Cyprinus carpio. PeerJ. 2014;2:e671. PMID 25405077. Available from: $10.7717 /$ peerj.671.

73. Pratheepa V, Sukumaran N. Specific and nonspecific immunostimulation study of Euphorbia hirta on Pseudomonas fluorescens-infected Cyprinus carpio. Pharmaceutical Biology. 2011;49(5):484-91. PMID: 21385104. Available from: 10.3109/13880209.2010.526615.

74. Ahmad SF, Khan B, Bani S, Kaul A, Sultan P, Ali SA. Immunosuppressive effects of Euphorbia hirta in experimental animals. Inflammopharmacology. 2013;21(2):161-8. PMID: 22710830 Available from: 10.1007/s10787-012-0144-6.

75. Tai W, He L, Zhang X, Pu J, Voronin D, Jiang S, et al. Characterization of the receptor-binding domain (RBD) of 2019 novel coronavirus: implication for development of RBD protein as a viral attachment inhibitor and vaccine. Cellular \& Molecular Immunology. 2020;17(6):613-20. PMID: 32203189. Available from: $10.1038 /$ s41423-020-0400-4.

76. Williams LA, Gossell-Williams M, Sajabi A, Barton EN, Fleischhacker R. Angiotensin converting enzyme inhibiting and anti-dipsogenic activities of Euphorbia hirta extracts. Phytotherapy Research. 1997;11(5):401-12. Available from: 10.1002/(SICI)1099-1573(199708)11:5<401::AIDPTR119>3.0.CO;2-T.

77. Brown EE, Rezaei R, Jamieson TR, Dave J, Martin NT, Singaravelu R. Characterization of Critical Determinants of ACE2SARS CoV-2 RBD Interaction. International Journal of Molecular Sciences. 2021;22(5):2268. PMID: 33668756. Available from: $10.3390 /$ ijms22052268. 
Ready to submit your manuscript? Choose Biomedpress and benefit from:

- Fast, convenient online submission

- Through peer-review by experienced researchers

- Rapid publication on acceptance

- Free of charge (without publication fees)

Learn more http://www.biomedpress.org/journals/
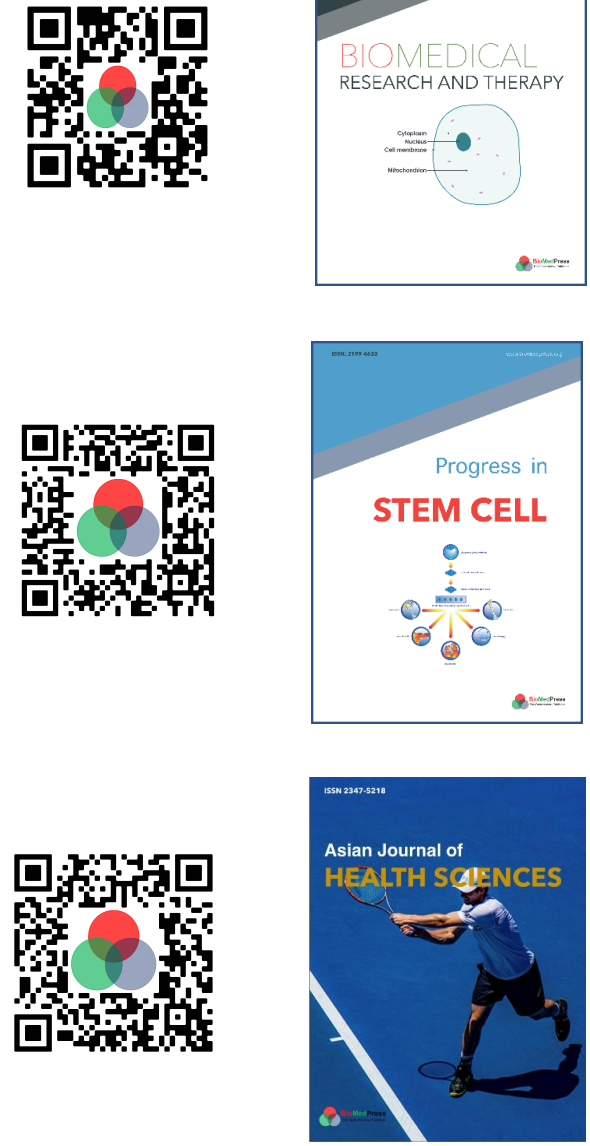

Asian Journal of Health Sciences

ISSN: 2347-5218

Indexed: Google Scholar

Acceptance Rate (2020): 72.89\%

Article Publishing Charge: Free

Submission to first editorial decision: 16.5 days

Biotechnological Research

ISSN: 2395-6763

Indexed: Google Scholar

Acceptance Rate (2020): $67.02 \%$

Article Publishing Charge: Free

Submission to first editorial decision: 28.5 days 